\title{
KEWENANGAN ABSOLUT LEMBAGA ARBITRASE
}

\author{
(Absolute Authority of Arbitration Institutions)
}

\author{
Pujiyono \\ Fakultas Hukum Universitas Sebelas Maret \\ Jl. Ir Sutami No. 36A Surakarta \\ Email:pujifhuns@staff.uns.ac.id
}

Naskah diterima: 2 Mei 2018; revisi: 12 Juli 2018; disetujui: 2 Agustus 2018

\begin{abstract}
Abstrak
Arbitrase sebagai model resolusi sengketa bisnis diakui berdasarkan Undang-Undang Nomor 30 Tahun 1999 tentang Arbitrase dan Alternatif penyelesaian Sengketa (UU Arbitrase). Putusan yang dibuat oleh lembaga arbitrase bersifat final dan binding, yang bersifat mengikat dan tidak ada upaya hukum lain. Namun demikian, tidak jarang pihak yang tidak puas atas putusan arbitrase mengajukan gugatan pembatalan maupun gugatan atas pokok perkara ke pengadilan, dengan dalih pengadilan tidak boleh menolak perkara yang diajukan oleh warga negara. Hal tersebut ditegaskan di dalam UndangUndang Nomor 48 Tahun 2009 tentang Kekuasaan Kehakiman (UU Kekuasaan Kehakiman). Akibatnya penyelesaian sengketa menjadi berlarut-larut dan tidak kunjung selesai. Penelitian ini menggunakan metode normatif dengan pendekatan perspektif. Teknik pengumpulan bahan hukum dilakukan melalui studi kepustakaan dengan menggunakan content analysis dengan logika deduktif. Hasil penelitian menunjukkan bahwa, kedudukan UU Arbitrase dan UU Kekuasaan Kehakiman adalah sederajat, oleh karena itu apabila ada benturan seharusnya digunakanasas lex spesialis derogat legi generale, peraturan yang khusus mengalahkan yang umum, sehingga UU Arbitrase harus didahulukan. Terhadap haltersebut berlaku courtlimitation sebagaimana diatur di dalam Pasal 3 dan Pasal 11 UU Arbitrase, bahwa pengadilan tidak berwenang memeriksa kasus yang ada klausulnya arbitrase, bahkan hakim pengadilan negeri wajib menolak.
\end{abstract}

Kata Kuci: sengketa bisnis, putusan arbitrase, gugatan, pengadilan

\begin{abstract}
Arbitration as a business dispute resolution model is recognized under Law Number 30 Year 1999 on Arbitration and Alternative Dispute Settlement. Arbitration's Decision is final and binding. Nevertheless, it is not uncommon for dissatisfied parties to the arbitration's decision, make an other legal efforts, like arbitration's decision cancellation or a lawsuit on the object of the case to the court, under the pretext of a court should not to reject a case filed by a citizen. This is confirmed in Law Number 48 Year 2009 on Judicial Authority. As a result the settlement of the dispute becomes protracted and does not go away. This research uses normative method with perspective approach. The technique of collecting legal materials is done through literature study using content analysis with deductive logic. The results show that the status of the Arbitration Law and the Law of Judicial Authority are the equivalent, therefore if there is a collision it should be used by lex specialist derogat legi generale principle, so the Arbitration Act should take precedence. The court limitation as stipulated in Article 3 and 11 of the Arbitration Law states that the court not authorized to check the cases in which the arbitration clause is in the contract, even the judges shall refuse.
\end{abstract}

Keywords: business dispute, arbitration's decision, lawsuit, court 


\section{A. Pendahuluan}

Sengketa dan bisnis harusnya dapat dipisahkan oleh batas, namun meskipun para pihak telah berusaha sekuat tenaga untuk mencegahnya, sengketa tetap dapat muncul di antara para pelaku bisnis. Sejatinya terjadi sangketa dagang tersebut oleh para pihak sangat tidak diharapkan, karena dapat menyulitkan masa depan hubungan dagang di antara mereka. ${ }^{1}$ Perselisihan yang terjadi antara para pihak karena adanya pelanggaran atau wanprestasi terhadap kesepakatan yang telah dituangkan dalam suatu kontrak, baik sebagian maupun keseluruhan oleh pihak-pihak atau salah satu pihak. ${ }^{2}$ Perselisihan dapat membesar menjadi sengketa yang menimbulkan akibat hukum antara satu dengan yang lain. ${ }^{3}$ Sengketa adalah pertentangan atau konflik antara orang-orang, kelompok-kelompok, atau organisasi-organisasi terhadap satu objek permasalahan. Sengketa terjadi karena adanya kepentingan yang sama yang saling diperebutkan. Subyek dapat berupa orang maupun badan hukum. Dalam konteks bisnis, maka kepentingan yang diperebutkan adalah kepentingan yang dapat dinilai secara ekonomi atau bernilai profit (tujuan ekonomi). Konflik dapat memicu benturan kepentingan yang berujung pada sangketa. Sengketa yang timbul akan menghambat aktivitas perdagangan dan bisnis apabila tidak diselesaikan secara cepat, bahkan bagi para pelaku usaha hal tersebut adalah suatu permasalahan yang merugikan karena menyita banyak waktu dan tenaga serta financial mereka. Sengketa bisnis tersebut harus segera diselesaikan guna untuk menjaga keseimbangan hubungan yang telah terbentuk dan penyelesaian ini harus dilakukan menurut hukum atau berdasarkan kesepakatan awal para pihak yang umumnya tercantum dalam perjanjian yang mereka buat.

Undang-undang telah menggariskan bahwa proses peradilan (termasuk dalam perkara perdata) wajib dilaksanakan secara cepat, sederhana dan biaya ringan. Namun kadang kondisinya sebaliknya, lambatnya proses pemeriksaan perkara akan mengurangi kewibawaan hukum dan pengadilan dimata masyarakat. ${ }^{4}$ Penyelesaian sengketa di pengadilan dapat berlarut-larut ${ }^{5}$ ditingkat Pengadilan Negeri, belum lagi di tingkat Pengadilan Tinggi dan Mahkamah Agung. ${ }^{6}$ Bahkan untuk sengketayang melibatkan hukum/ negara yang berbeda, maka sistemnasional pengadilan di suatu negara dianggap sebagai hambatan untuk mencari resolusi sengketa. ${ }^{7}$

Tren penyelesaian sengketa saat ini tidak melulu melalui pengadilan. Terdapat fakta dipilihnya jalur di luar pengadilan (out of court atau non litigasi), salah satunya adalah arbitrase. Arbitrase, merupakan cara penyelesaian

A Sony Keraf, Etika Bisnis: Tuntutan dan Relevansinya, Pustaka Filsafat (Yogyakarta:Kanisius, 1998), hlm. 76.

2 Nurnaningsih Amriani, Mediasi Alternatif Penyelesaian Sengketa Perdata di Pengadilan. (Jakarta: PT. Raja Grafindo Persada, 2012), hlm. 12.

3 Pujiyono,Eksistensi Model Penyelesaian Sengketa antara Nasabah dan Bank Syariah di Indonesia(Solo: SmartMedia, 2012), hlm. 69.

4 Bachtiar Efendi, dkk, Surat Gugat dan Hukum Pembuktian dalam Perkara Perdata, (Bandung: Citra Aditya Bakti, 1992), hlm. 6.

5 Retnowulan Sutantio dan Iskandar Oeripkartawinata, Hukum Acara Perdata dalam Teori dan Praktek,(Bandung:Alumni, 1988), hlm. 10.

6 M. Khoidin, Pelaksanaan Asas Peradilan Cepat, Artikel(Surabaya: Harian Surya, 1996): 6.

7 Sewart, K. Online Arbitration Of Cross-border, Business To Consumer Disputes, 56, (2002).: 1112. 
sengketa perdata di luar pengadilan, berdasarkan pada perjanjian arbitrase yang dibuat oleh para pihak, dan dilakukan oleh arbiter yang dipilih dan diberi kewenangan untuk mengambil keputusan. Para pihak selain lebih leluasa, juga diberikan kewenangan dalam memilih arbiternya. ${ }^{8}$ Lahirnya Undang-Undang Nomor 30 Tahun 1999 tentang Arbitrase dan Alternatif Penyelesaian Sangketa (UU Arbitrase) juga merupakan upaya pemerintah Republik Indonesia dalam menyediakan perangkat hukum guna memenuhi kebutuhan pasar, baik pasar nasional maupun pasar global (internasional). Dalam penjelasan umum UU Arbitrase juga telah ditegaskan kelebihan arbitrase dibandingkan dengan lembaga peradilan umum, yaitu sebagai berikut: 1) Dijamin kerahasiaan sangketa para pihak; 2) Dapat dihindari keterlambatan yang diakibatkan karena hal prosedural dan administrative; 3) Para pihak dapat memilih arbiter yang menurut keyakinannya mempunyai pengetauan, pengalaman serta latar belakang yang cukup mengenai masalah yang disangketakan, jujur dan adil; 4) Para pihak dapat menentukan pilihan hukum untuk menyelesaikan masalahnya serta proses dan tempat penyelenggaraan arbitrase; 5) Putusan arbiter merupakan putusan yang mengikat para pihak dan dengan melalui tata cara (prosedur) sederhana saja ataupun langsung dapat dilaksanakan.

Meskipun arbitrase adalah model resolusi mini trial yang menghasilkan keputusan, tetapi upaya perdamaian sangat dicari oleh para arbiter dalam menyelesaikan sengketa. ${ }^{9}$ Dalam memeriksa dan memutus sengketa, arbiter atau majelis arbiter selalui mendasarkan diri pada hukum, yaitu hukum yang telah dipilih oleh para pihak yang bersengketa (choice of law). Meskipun demikian, tidak tertutup kemungkinan bahwa para arbiter, apabila dikendaki oleh para pihak, memutus atas dasar keadilan dan kepatutan. ${ }^{10}$

Penyelesaian sengketa melalui arbitrase didasarkan pada kesepakatan bersama (mutual consent) yang tertuang di dalam perjanjian arbitrase. Faktor kesukarelaan dan kesadaran bersama, merupakan landasan keabsahan ikatan perjanjian arbitrase. Berdasarkan hal tersebut, keabsahan dan mengikatnya setiap perjanjian arbitrase, harus memenuhi ketentuan Pasal 1320 KUH Perdata.Adanya perjanjian tertulis meniadakan hak para pihak untuk mengajukan penyelesaian sangketa atau beda pendapat yang termuat dalam perjanjiannya ke pengadilan negeri. Para pihak yang telah terikat dengan perjanjian arbitrase tidak mempuyai hak untuk mengajukan penyelesaian sangketa di Pengadilan Negeri, dan dalam hal ini pun Pengadilan Negeri tidak berwenang untuk mengadili sangketa para pihak yang telah terikat dengan perjanjian arbitrase.

Berdasarkan Pasal 60 UU Arbitrase, bahwa putusan arbitrase bersifat final dan mempunyai kekuatan hukum tetap dan mengikat para pihak. Para pihak harus menghormati dan tunduk kepada putusan arbitrase tersebut dengan melaksanakan isi putusan arbitrase atas dasar itikad baik. Penjelasan Pasal 60 UU Arbitrase, bahwa terhadap putusan arbitrase tidak dapat diajukan banding, kasasi atau peninjauan kembali. Putusan arbitrase tidak disediakan

\footnotetext{
Jean R. Sternlight. HeinOnline -- 74 Wash. U. L. Q. 637 (1996): 638.

9 Frans Hendra Winarta, Hukum Penyelesaian Sangketa ; Arbitrase Nasional Indonesia dan Internasional (Jakarta: Sinar Grafika, 2013), hlm. 62-63.

$10 \quad$ Pujiyono, (2012),Op cit,hlm: 74-75..
} 
upaya hukum, baik upaya hukum biasa maupun upaya hukum luar biasa. Final and binding merupakan salah satu kelebihan yang dimiliki arbitrase karena dapat memberikan kepastian hukum secara efektif bagi para pihak yang bersengketa dan menghindarkan sengketa tersebut menjadi semakin berkepanjangan. Fakta yang terjadi tidak semua putusan yang dihasilkan melalui forum arbitrase ini akan memberikan kepuasan kepada para pihak. Sehingga pihak yang tidak puas dan merasa terbentur dengan karakter arbitrase yang final dan binding tersebut, maka melakukan upaya dengan meempuh jalur lain, yakni pengadilan. Di dalam pengadilan berlaku suatu Ius Curia Novit yang berarti hakim dianggap mengetahui semua hukum sehingga Pengadilan tidak boleh menolak memeriksa dan mengadili perkara. Dalam konteks normatif, asas ini dikuatkan dengan Pasal 10 ayat (1) Undang-Undang Nomor 48 Tahun 2009 tentang Kekuasaan Kehakiman (UU Kekuasaan Kehakiman), yang menyebutkan bahwa: Pengadilan dilarang menolak untuk memeriksa, mengadili, dan memutus suatu perkara yang diajukan dengan dalih bahwa hukum tidak ada atau kurang jelas, melainkan wajib untuk memeriksa dan mengadilinya. Hakim bisa menciptakan hukum sendiri, sehingga hakim mempunyai kedudukan tersendiri sebagai pembentuk undang-undang selain Lembaga Pembuat Undang-undang.

Atas dasar inilah maka muncul benturan hukum antara UU Arbitrase dan UU Kekuasaan Kehakiman. Salah satu pihak yang kalah dimungkinkan tidak melaksanakan putusan arbitrase secara sukarela, dan hal ini bisa membuat frustasi bagi pihak yang menang. Untuk dapat dilaksanakannya putusan arbitrase tersebut pasti harus melibatkan pengadilan. Keterlibatan pengadilan tidak dapat dihindari, mengingat pemaksaan atas putusan arbitrase baik nasional maupun internasional hanya bisa dilakukan oleh pengadilan dalam bentuk penetapan eksekusi. Akibatnya penyelesaian sengketa yang diharapkan dapat selesai dalam waktu cepat, justru akan menjadi lama.

Contoh kasus yang terkait adalah Putusan Nomor 480 B/Pdt.Sus-Arbt/2017 antara BANI (Badan Nasional Indonesia) sebagai Termohon I dan PT. Indonesia Power Unit Bisnis Pembangkitan Semarang sebagai Temohon II dengan Konsorsium (PT. Boma Bisma Indra Persero - PT. Indo Surya Persada). Kasus ini berawal dari sengketa bisnis antara para pihak untuk diselesaikan di BANI. Setelah adanya putusandariBANI, PT.IndonesiaPowerUnitBisnis Pembangkitan Semarang sebagai Termohon II dinyatakan kalah dalam putusan tersebut. Tidak terima dengan kekalahan tersebut, PT. Indonesia Power Unit Bisnis Pembangkitan Semarang menempuh upaya banding ke Pengadilan Negeri Jakarta dengan dasar bahwa Konsorsium (PT. Boma Bisma Indra Persero - PT. Indo Surya Persada) telah melakukan wanprestasi dan merugikan penggugat dalam perjanjian proyek pemborongan pekerjaan Retubing LP Evaporator dan LP Economizer HRSG 1.2 yang terletak di PLTGU Tambaklorok Semarang dengan nilai kontrak Rp 10.188.079.000,00 (sepuluh miliar seratus delapan puluh delapan juta tujuh puluh sembilan ribu rupiah).Akibat adanya gugatan ke pengadilan olehPT. Indonesia Power Unit Bisnis Pembangkitan Semarang, putusan BANI tidak dapat dieksekusi. PT. Boma Bisma Indra Persero - PT. Indo Surya Persada menjadi terhambat untuk mendapatkan hak-hak keperdataannya kembali.

Contoh lain adalah kasus yang sangat familiar pada tahun 2001-2004, yakni sengketa PERURI dengan PT BARUTAMA Kudus. Putusan 
BANI No. 147/IV/ARBBANI/2001 memenangkan PERURI dan mengalahkan PT BARU TAMA, karena putusan tersebut diangap merugikan, $\mathrm{PT}$ BARUTAMA mengajukan gugatan pembatalan melalui PN KUDUS dengan register No. 30/ Pdt.P/2002/PN.KDS. Majelis hakim PN Kudus membatalkan putusan arbitrase yang memenangkan PERURI dan melanjutkan pemeriksaan perkara sengketa itu. PERURI merasa haknya dicerabut oleh PN Kudus, kemudian banding ke Mahkamah Agung. Kasus ini berlarut-larut bahkan mendapat perhatian dunia internasional terkait dengan ketidakpastian kewenangan lembaga arbitrase sebagai model resolusi sengketa bisnis.Ada lagi kasus digugatnya Putusan Nomor: 265 B/Pdt. Sus-Arbt/2016 antara Kepala Dinas Perhubungan dan Transportasi Provinsi DKI Jakarta dengan PT. IRFANI DEWI dan BANI. Kasus ini berawal dari sengketa proyek antara para pihak yang dibawa oleh para pihak untuk diselesaikan di BANI. Putusan BANI menyatakan bahwa Kepala Dinas Perhubungan dan Transportasi DKI Jakarta dinyatakan kalah. Tidak terima, Kepala Dinas Perhubungan dan Transportasi DKI Jakarta mengajukan banding ke Pengadilan Negeri Jakarta Pusat dengan dasar bahwa PT. IRFANI DEWI sebagai termohon I dan BANI sebagai termohon II melakukan wanprestasi dalam perjanjian yang mereka sepakati dalam sengketa proyek pengadaan paket bus Transjakarta dengan PT. IRFANI DEWI. Akibatnya, hak-hak keperdataan yang seharusnya didapatkan oleh PT. IRFANI DEWI menjadi terhambat karena adanya gugatan ke pengadilan.

Tiga kasus di atas menandakan bahwa eksistensi putusan arbitrase sebagai model resolusi sengeta bisnis tidak ditaati. Terdapat pertentangan antara UU Arbitrase dan UU Kekuasaan Kehakiman, yang menimbulkan ketidakpastian, sehingga dapat dimanfaatkan oleh pihak yang merasa dirugikan oleh putusan arbitrase dengan melakukan gugatan ke pengadilan. Resiko akibat celah hukum inilah yang menarik utuk dikaji, berdasar latar belakang di atas, maka masalahyang dikaji dalam tulisan ini adalah mengenai: kewenangan absolut perkara dengan klausula arbitrase, disharmoni UU Kekuasaan Kehakiman dan UU Arbitrase, dan mengenai kekuatan eksekutorial putusan arbitrase.

\section{B. Metode Penelitian}

Jenis penelitian ini adalah penelitian normatif, bersifat preskriptif. Pendekatan yang digunkan adalah pendekatan undang-undang (statue approach). Pendekatan ini dilakukan dengan menelaah semua undang-undang dan regulasi yang bersangkutan dengan isu hukum yang sedang ditangani guna memahami hierarki dan asas-asas dalam peraturan perundangundangan. ${ }^{11}$ Bahan hukum primer yang digunakan dalam penelitian hukum ini, antara lain:Undang-Undang Nomor 30 Tahun 1999 tentang Arbitrase dan Alternatif Penyelesaian Sengketa; Undang-Undang Nomor 48 Tahun 2009 tentang Kekuasaan Kehakiman; Kitab Undang Undang Hukum Perdata, dan Herziene Inlandsch Reglement (HIR). Sedangkan bahan hukum sekunder berupa semua publikasi yang bukan merupakan dokumen-dokumen resmi. Publikasi tentang hukum meliputi buku-buku, teks, kamus hukum, jurnal-jurnal hukum dan komentar-komentar atas putusan pengadilan.

11 Peter Mahmud Marzuki, Penelitian Hukum (Jakarta: Kencana, Cet. 7, 2011), hlm. 93. 
Teknikpengumpulan bahan hukum dilakukan melalui studi dokumen (studi kepustakaan) dengan menggunakan content analysis. Teknik ini berguna untuk mendapatkan landasan teori dengan mengkaji, mempelajari, dan memberi catatan terhadap semua bahan hukum. Content analysis menggunakan penarikan kesimpulan secara deduktif.

\section{Pembahasan}

\section{Kompetensi Absolut Perkara dengan Klausula Arbitrase}

Di negara-negara seperti Amerika Serikat, Australia, hampir $90 \%$ sengketa bisnis diselesaikan oleh para pihak dengan cara non litigasi. ${ }^{12}$ Tetapi sejatinya arbitrase tidaklah seramai sekarang ini, apalagi dalam lapangan investasi, "Arbitration of investment disputes was not once as widely used as it is now".13 Para pihak sepakat menggunakan arbitrase diketahui dari kalusula arbitrase yang dibuat secara tertulis oleh para pihak. "The arbitration clause usually defines the process by which the arbitrator will be selected; often it also specifies the qualifications the arbitrator is required to have or his/her identity." 14 Pilihan para pihak yang bersengketa memilih menyelesaikan sengketanya melalui arbitrase mengandung arti bahwa para pihak sudah terikat dalam perjanjian arbitrase, yang telah dibuat sebelum adanya sengketa (pactum de compromittendo) atau perjanjian yang dibuat setelah adanya sengketa (akta kompromis). Akibatnya para pihak yang telah terikat dengan perjanjian arbitrase tidak mempuyai hak untuk mengajukan penyelesaian sengketa di Pengadilan Negeri. Begitu pula sebenarnya hal tersebut menutup Pengadilan Negeri tidak berwenang untuk mengadili sengketa para pihak yang telah terikat dengan perjanjian arbitrase. Perikatan arbitrase adalah perikatan yang lahir dari perjanjian, dengan melihat isi perjanjian yang sudah disepakati oleh para pihak. Perikatan arbitrase harus dibuat ke dalam suatu akte, baik sebelum adanya sengketa maupun setelah adanya sengketa, kemudian lembaga arbitrase mensyaratkan harus adanya perjanjian tertulis apabila ingin menyelesaikan sengketanya melalui arbitrase. ${ }^{15}$

Pilihan forum (choice of jurisdiction) dalam kontrak yang memuat klausula arbitrase bagi kontrak yang memuat klausula arbitrase bagi para pihak yang berperkara membawa akibat hukum berupa peniadaan hak para pihak untuk mengajukan penyelesaian sengketa yang termuat dalam perjanjiannya ke pengadilan negeri. Demikian juga pengadilan juga harus menolak atau tidak akan campur tangan di dalam suatu penyelesaian sengketa yang telah ditetapkan melalui arbitrase, kecuali dalam halhal tertentu yang ditetapkan dalam undangundang ini.

Kompetensi absolut arbitrase secara normatif akan lahir ketika para pihak dalam membuat perjanjian dengan tegas menyatakan bahwa mereka akan menyelesaikan perselisihan mereka melalui forum arbitrase. Dengan demikian, pengadilan tidak memiliki wewenang untuk mengadili sengeketa tersebut. Terlebih

12 Marwah M. Diah, Prinsip dan Bentuk-bentuk Alternatif Penyelesaian Sengketa di Luar Pengadilan. Jurnal Hukum dan Dinamika Masyarakat. Vol. 5 (2008): 111

13 Franck, S. D. The Legitimacy Crisis in Investment Treaty Arbitration: Privatizing Public International Law Through Inconsistent Decisions, 73(4), (2005) : 1536.

14 Iossa, E. Reputational Concerns in Arbitration : Decision Bias and Information Acquisition *, (June, 2007 ): 2.

15 Joni Emirzon, Alternatif Penyelesaian Sengketa di Luar Pegadilan(Jakarta:PT Gramedia Pustaka Utama, 2001), hlm. 100 . 
dengan terbitnya undang undang arbitrase, kedudukan dan kewenangan arbitrase menjadi semakin jelas dan kuat, karena sudah ada dasar pengaturan yang tegas menyangkut kompetensi absolut arbitrase. Meskipun demikian dalam praktik selama ini penulis masih menemukan adanya penyimpangan, dimana klausula arbitrase terkadang diabaikan pengadilan. Oleh karena itu, itikad baik para pihak dan sikap pengadilan yang konsisten sesungguhnya juga punya peranan besar untuk mengembangkan arbitrase, dimana proses arbitrase perlu mendapat campur tangan pengadilan, demi memperlancar proses arbitrase itu sendiri.

Kompetensi absolut arbitrase sangat penting, karena dengan adanya Undang Undang Kekuasaan Kehakiman telah memberikan pengaturan tentang diperbolehkannya penyelesaian sengketa melalui arbitrase. Dijelaskan dalam Pasal 3 ayat (1) disebutkan bahwa 'ketentuan ini tidak menutup penyelesaian perkara di luar peradilan Negara melalui perdamaian atau arbitase". Dengan demikian, penyelesaian perkara di luar pengadilan atas dasar perdamaian atau melalui arbitrase tatap diperbolehkan, tergantung forum penyelesaian sengketa yang dipilih oleh pihak-pihak yang berperkara (Pasal 1 UU Arbitrase). Dalam hal ini berarti inisiatif dan keaktifan para pihak dalam menentukan pilihan forum penyelesaian sengketa menjadi sangat penting, karena penentuan pilihan ini terkait dengan kompetensi atau kewenangan absolut lembaga yang memiliki kewenangan untuk memeriksa dan memutus perkara tersebut.

Kewenangan absolut merupakan wewenang badan peradilan atau forum lainnya untuk memeriksa suatu perkara tertentu yang secara mutlak tidak dapat diperiksa oleh badan peradilan atau forum lainnya sesuai dengan aturan perundang-undangan yang berlaku. Kewenangan absolut juga berlaku dalam arbitrase. Sebagai contoh, ketika dalam suatu perjanjian jual beli, para pihak sepakat untuk mengajukan sengketa melalui arbitrase, maka apabila sengketa timbul para pihak harus mematuhi perjanjian yang telah mereka buat, dan memajukan sengketa tersebut ke arbitrase. Adanya klausula arbitrase akan menyebabkan perselisihan yang timbul diantara para pihak menjadi wewenang absolut arbitrase. Ketika sengketa tersebut sudah jatuh ke dalam wewenang absolut arbitrase, maka semestinya lembaga peradilan tidak lagi memiliki wewenang untuk memeriksa perselisihan tersebut (Pasal 3 dan 11 UU Arbitrase).

Kenyataannya, penyimpangan dapat terjadi, misalnya saja, salah satu pihak mengajukan gugatan terhadap perkara dalam kontrak berklausula arbitrase ke pengadilan negeri. Sikap pengadilan negeri pada umumnya tidak seragam, ada yang menyatakan gugatan tidak dapat diterima (Niet Ontvankelijke Verklaard) atau yang biasa disebut NO, tetapi ada pula yang menerima dan mengabulkan gugatan tersebut. Akan tetapi, pada umumnya ketika kasustersebut sampai pada Mahkamah Agung, Mahkamah Agung berpegang teguh pada pendiriannya dengan menyatakan gugatan tidak diterima. Mahkamah Agung sepertinya berpendirian bahwa pengadilan tidak berwenang memeriksa perkara yang sudah terikat perjanjian arbitrase, karena hal tersebut, merupakan wewenang absolut lembaga arbitrase. ${ }^{16}$

Putusan Mahkamah Agung Republik Indonesia sebagian besar tetap konsisten

16 Bambang Sutiyoso, Penyelesaian Sengketa Bisnis(Yogyakarta: Citra Media, 2006), hlm. 26. 
pada persoalan kompetensi absolut arbitrase, yaitu bahwa pengadilan tidak berwenang memeriksa dan mengadili sengketa yang di dalam perjanjian para pihak telah dicantumkan klausula arbitrase. Kebanyakan praktik yang terjadi saat ini masih dapat dijumpai pengadilan negeri yang melayani gugatan pihak yang kalah dalam arbitrase. Beberapa perkara menunjukkan bahwa walaupun perjanjian telah memuat klausula arbitrase namun salah satu pihak tetap mengajukan gugatan ke pengadilan negeri karena beberapa alasan.Kasus PT. Indonesia Power Unit Bisnis Pembangkitan Semarang melawan konsorsium (PT. Boma Bisma Indra Persero - PT. Indo Surya Persada), sengketa anatara PT PERURI dan PT BARUTAMA, serta kasus Kepala Dinas Perhubungan dan Transportasi Provinsi DKI Jakarta dengan PT. IRFANI DEWI membuktikan bahwa klausula arbitrase dapat disimpangi oleh pihak yang dirugikan.

Keterlibatan pengadilan dalam perkara yang ada klausula arbitrasenya memang bukan diskusi baru-baru saja. Sejak kemunculan arbitrase di Amerika diskusi ini sudah mengemuka. ${ }^{17}$ UU Arbitrase memberikan dasar pengaturan yang tegas menyangkut kompetensi absolut arbitrase. Berdasarkan undang-undang ini pranata arbitrase di Indonesia memiliki kedudukan dan kewenangan yang semakin jelas dan kuat. Dalam Pasal 3 UU Arbitrase disebutkan bahwa pengadilan negeri tidak berwenang untuk mengadili sengketa para pihak yang telah terikat dengan perjanjian arbitrase. Kemudian pada Pasal 11 UU Arbitrase kembali mempertegas yurisdiksi absolut arbitrase yang disebut dalam Pasal 3 tersebut, dengan secara tegas. Ketentuan Pasal 11 ayat (2) UU Arbitrase dapat membuka kemungkinan adanya intervensi pengadilan terhadap suatu perkara yang mengandung klausula arbitrase yaitu dalam hal-hal tertentu yang ditetapkan dalam undang-undang. Dengan adanya ketentuan pasal tersebut, maka kompetensi absolut arbitrase lahir ketika para pihak membuat perjanjian dengan tegas bahwa mereka akan menyelesaikan perselisihan mereka melalui forum arbitrase. Dengan demikian, pengadilan tidak memiliki wewenang untuk mengadili sengketa tersebut kecuali jika para pihak sepakat untuk menyelesaikan melalui jalan pengadilan.

\section{Disharmoni UU Kekuasaan Kehakiman dan UU Arbitrase}

Eksistensi UU Arbitrase sebenarnya sempat dipermasalahkan di Mahkamah Konstitusi (MK). Namun Judicial Review tidak berkaitan dengan kewenangan lembaga rabitrase, tetapi terhadap multitafsir Penjelasan Pasal 70 UU Arbitrase tentang pembatalan putusan arbitrase. MK melalui keputusan bernomor 15/PUU/XII/2014 menyatakan bahwa Penjelasan Pasal 70 UU Arbitrase bertentangan dengan UUD 1945 dan tidak mempunyai kekuatan hukum mengikat. MK menilai bahwa Pasal 70 UU Arbitrase sudah cukup jelas (expressis verbis), sehingga tidak perlu ditafsirkan lain. Justru Penjelasan Pasal 70 menimbulkan multitafsir, sebab, ketentuan itu dapat ditafsirkan apakah alasan pengajuan permohonan harus dibuktikan secara pidana oleh pengadilan terlebih dahulu.

Mengenai eksistensi arbitrase sebagai model resolusi sengketa bisnis tetap diakui, sepanjang memuat perjanjian dengan klausula

17 Drahozar, C. R. Party Autonomy and Interim Measures In International Commercial Arbitration, 189(2003), hlm. 184-185 
arbitrase. Pengadilan tidak berwenang untuk mencampuri suatu sengketa bilamana para pihak telah mencantumkan sebuah klausula arbitrase dalam kontrak. ${ }^{18}$ Tujuan arbitrase sebagai alternatif bagi penyelesaian sengketa melalui pengadilan akan menjadi sia-sia karena pengadilan masih bersedia memeriksa sengketa yang sejak semula disepakati diselesaikan melalui arbitase. ${ }^{19}$ Campur tangan pengadilan dalam hal-hal tertentu masih dimungkinkan sepanjang tindakan campur tangan tersebut dilakukan untuk memperlancar proses arbitrase, misalnya: untuk memperoleh kekuatan eksekutorial dari suatu putusan arbitrase. Pelaksanaan putusan arbitrase, telah diambil berdasarkan salah satu dari hal-hal berikut: putusan tidak sesuai dengan perjanjian, putusan dijatuhkan berdasarkan dokumen palsu, ditemukan dokumen yang bersifat menentukan yang disembunyikan pihak lawan, dan putusan diambil dari hasil tipu muslihat sebagaimana yang disebutkan dalam Pasal 70 UU Arbitrase. Apabila salah satu pihak sudah terlanjur menyerahkan sengketanya ke pengadilan, maka pengadilan negeri berdasarkan permohonan para pihak lain harus menolaknya. Hal ini sesuai dengan ketentuan Pasal 3 UU Arbitrase. Penyelesaian sengketa sendiri dapat dimulai setiap saat. Mulai dari saat sengketa itu timbul sampai pada saat sebelum arbiter memberikan keputusannya. ${ }^{20}$

Larangan campur tangan pengadilan hanya untuk menegaskan bahwa arbitrase adalah sebuah lembaga yang independen sehingga pengadilan wajib menghormati lembaga arbitrase. Meskipun arbitrase merupakan suatu lembaga independen yang terpisah dari pengadilan, tidak berarti bahwa tidak ada kaitan erat di antara keduanya. Lembaga arbitrase membutuhkan dan tergantung pada pengadilan, misalnya dalam pelaksanaan putusan arbitrase. ${ }^{21}$ Tetapi pemeriksaan pokok perkara arbitrase di pengadilan tidak diperbolehkan dan tidak boleh melihat alasan-alasan yang dipakai bagi putusan arbitrase bersangkutan. Jadi tidak ada acara lagi seperti dalam banding, serta diperiksa secara menyeluruh semua persoalan hukum yang telah dijadikan dasar untuk putusan arbitrase yang dimohon pelaksanaannya ini. Menurut penjelasan Pasal 15 ayat (1) UU Arbitrase dinyatakan bahwa putusan arbitrase sudah mengikat dan diakui serta dapat dilaksanakan seperti putusan Pengadilan biasa, mengenai dua hal penting, yaitu:

1) Bahwa antara para pihak dengan jelas menyatakan dalam perjanjian arbitrase dengan kekuatan undang-undang, bahwa putusan ini akan diakui sebagai pengikat.

2) Hal yang kedua dari Pasal 15 ayat (1) ini mengatakan atas permohonan kepada Pengadilan Negeri hanya dapat diajukan penolakan yang dasarnya terbatas sekali dan dinyatakan dalam perumusan ayat ketiga. Pada pasal ini menentukan bahwa putusan akhir dari arbitrase menurut penjelasan"baik yang nasional maupun yang arbitrase asing" memenuhi syarat "dapat dilaksanakan".

Sifat sebagai putusan pengadilan yang berkekuatan hukum tetap, yang tercantum dalam Pasal 4 UU Arbitrase yang mengatur mengenai harus diperlakukan putusan arbitrase

\footnotetext{
18 Priyatna Abdurrasyid, Arbitrase \& Alternatif Penyelesaian Sengketa, (Jakarta: Fikahati Aneska, 2002),hlm. 79.

19 Erman Rajagukguk, Arbitrase Dalam Putusan Pengadilan, (Jakarta: Chandra Pratama, 2000), hlm. 13-14.

20 Priyatna Abdurrasyid, (2002), op cit, hlm. 63.

21 Gatot Soemartono, Arbitrase dan Mediasi di Indonesia (Jakarta: PT Gramedia Pustaka Utama, 2006), hlm. 71.
} 
ini. Ketua pengadilan negeri dapat dan akan melaksanakan putusan arbitrase "seolah-olah putusan tersebut merupakan perintah putusan yang berkekuatan hukum tetap". Maka ada persamaan status dari perkara arbitrase yang sudah final ini sebagai putusan pengadilan negeri yang sudah berkekuatan hukum tetap. Dinyatakan lebih lanjut dalam Pasal 4 ini, jika diminta untuk menolak pengakuan atau pelaksanaan satu putusan, maka Ketua Pengadilan Negeri bisa menunda persidangan untuk satu jangka waktu tertentu.

Pasal 15 ayat (5) menentukan bahwa terhadap putusan Ketua Pengadilan Negeriuntuk mengakui pelaksanaan putusan arbitrase tidak dapat dilakukan banding, baik di Mahkamah Agung maupun di Pengadilan banding manapun tidak boleh menanganiatau mempertimbangkan permohonan banding atas putusan tersebut. Sebaliknya jika Ketua Pengadilan Negeri menolak untuk mengakui dan melaksanakan putusan arbitrase, dapat dilakukan banding. Mahkamah Agung akan menanganinya dan mempertimbangkan untuk mengambil putusan atas banding tersebut secepatnya dan tidak melampaui 90 hari sejak permohonan banding disampaikan kepada Mahkamah Agung. Dan Mahkamah Agung mengatakan tata cara untuk mempercepat penyelesaian banding ini. Tidak ada tata cara demikian itu tidak akan mempengaruhi kewajiban Mahkamah Agung "untuk menangani, mempertimbangkan dan memutuskan banding tersebut sesuai dengan syarat-syarat yang ditetapkan dalam ketentuan ini". Alasannya tentu untuk mempersingkat kemungkinan dapat diselesaikannya dan dilaksanakannya putusan bersangkutan. Perlu mendapat penjelasan tentang batas waktu untuk mengeluarkan putusan mengenai dapat tidaknya putusan arbitrase dilaksanakan serta batas waktu untuk melaksanakan eksekusi jika putusan arbitrase dinyatakan oleh Pengadilan dapat dilaksanakan.

Adanya ketidakharmonisan di antara undang-undang kekuasaan kehakiman dengan undang-undang arbitrase terkait dengan adanya celah hukum yang dapat digunakan para pihak yang bersengketa yang tidak puas dengan putusan arbitrase yang sudah bersifat final and binding, sehingga para pihak dapat mengajukan gugatan kembali dalam sengketa yang sama melalui Pengadilan Negeri. Ketidakharmonisan peraturan tersebut dapat dilihat dari ketentuan Pasal 10 UU Kekuasaan Kehakiman yang melarang pengadilan untuk menolak, memeriksa, memutus dan mengadili suatu perkara yang diajukan, sehingga menimbulkan problematika terkait independensi penyelesaian sengketa melalui arbitrase yang seharusnya bersifat final and binding. Berdasarkan ketentuan tersebut, maka hakim dipaksa atau wajib turut serta menentukan mana yang merupakan hukum dan mana yang tidak. Maksud dari Pasal 10 Undang-undang Kekuasaan Kehakiman ialah untuk membuktikan ruang penemuan hukum sangat terbuka, sehingga tidak satupun perkara yang masuk ke pengadilan menjadi terbengkalai hanya karena belum ada undang-undang yang mengaturnya secara eksplisit. Apabila ditinjau dari teori sistem hukum yang dikemukakan oleh Lawrence Friedman, bahwa efektif dan berhasil tidaknya penegakan hukum tergantung pada unsur-unsur sistem hukum itu, yang terdiri dari struktur hukum (legal structure), substansi hukum (legal substance) dan budaya hukum (legal culture). Sehingga menurut penulis berdasarkan teori tersebut adanya problematika terkait dengan substansi hukum yaitu ketidakharmonisan antara undang-undang 
kekuasaan kehakiman dengan undang-undang arbitrase.

Budaya hukum adalah meliputi pandangan, kebiasaan maupun perilaku dari masyarakat mengenal pemikiran nilai-nilai dan pengharapan dari sistim hukum yang berlaku dengan, perkataan lain, budaya hukum itu adalah iklim dari pemikiran sosial tentang bagaimana hukum itu diaplikasikan, dilanggar atau dilaksanakan. Terlihat dari budaya hukum para pihak yang bersengketa bahwa ketika putusan sudah dibacakan dan apabila salah satu pihak merasa belum puas akan hasil putusan yang telah dibacakan dan dapat mengajukan keberatan atau banding ke Pengadilan Negeri. Padahal dalam arbitrase sendiri sama sekali tidak ada upaya hukum apapun yang dapat dilakukan.

Sinkronisasi peraturan perundangundangan sangat dibutuhkan untuk mencapai suatu keadilan serta peraturan perundangundangan dapat terlaksana secara efektif dan efisien. Harmonisasi hukum merupakan unsur penting untuk pencapaian tujuan ditetapkannya peraturan perundang-undangan, karena Indonesia sebagai Negara yang berdasarkan hukum terdapat banyak peraturan perundangundangan yang mengatur berbagai aspek dan berbagai aktivitas kehidupan berbangsa dan bernegara. Demikian banyak peraturan perundang-undangan ditetapkan merupakan konsekuensi logis dari penjabaran konstitusi, karena tidak mungkin semua kegiatan berbangsa dan bernegara akan dimuat dalam satu konstitusi secara lengkap, untuk itu penjabarannya dilaksanakan dengan peraturan perundang-undangan sesuai bidang dan kepentingannya masing-masing, salah satunya di bidang penyelesaian sengketa arbitrase.

Peraturan dibuat untuk dijalankan, namun arena perbedaan latar belakang dan faktor- faktor lainnya, kadang kala menimbulkan antar peraturan tersebut menjadi tidak selaras. Penerapan berbagai peraturan perundangundangan secara bersama-sama tanpa upaya harmonisasi atau penyelarasan pasti akan menimbulkan masalah. Pengaturan tentang perlu adanya sinkronisasi atau harmonisasi hukum dapat ditemukan dalam Pasal 18 ayat (2) Undang-Undang Nomor 12 Tahun 2011 tentang Pembentukan Peraturan Perundang-undangan, menetapkan bahwa: Pengharmonisasian, pembuatan dan pemantapan konsepsi RUU yang berasal dari presiden, dikoordinasikan oleh menteri yang tugas dan tanggung jawabnya di bidang peraturan perundangundangan, sedangkan dalam Pasal 6 ayat (1) diatur bahwa prinsip keseimbangan, keserasian dan keselarasan, antara kepentingan individu dan masyarakat dengan kepentingan bangsa dan Negara, merupakan salah satu asas materi muatan setiap peraturan perundang-undangan. Walaupun mekanisme dalam pembentukan hukum secara jelas diatur untuk adanya harmonisasi, namun dalam kenyataannya tetap saja banyak peraturan perundang-undangan yang ditetapkan disharmoni satu sama lain, karena untuk mengharmonisasikan peraturan perundang-undangan tidaklah mudah dan memerlukan langkah-langkah dan metode yang tepat, sesuai dengan prinsip-prinsip dasar dari pengkajian ilmu pengetahuan hukum.

Peraturan perundang-undangan penyelesaian sengketa arbitrase ada tiga komponen peraturan yang berhubungan erat dan perlu diharmonisasikan, ketiga komponen ini diatur dan tuduk dalam rezim-rezim hukum tersendiri. Rezim hukum masing-masing kelompok peraturan perundang-undangan, dilaksanakan dengan peraturan pelaksana yang juga cukup banyak, akibatnya dalam satu kelompok 
perundang-undangan saja dapat menyebabkan disharmonisasi satu sama lain, apalagi antar kelompok perundang-undangan.

Penyebab terjadinya disharmonisasi aturan perundang-undangan menurut kemenkumham, ada 6 (enam) faktor, yaitu:

1) Pembentukan dilakukan oleh lembaga yang berbeda dan sering dalam kurun waktu yang berbeda;

2) Pejabat yang berwenang untuk membentuk peraturan perundang-undangan bergantiganti baik karena dibatasi oleh masa jabatan, alih tugas atau pergantian;

3) Pendekatan sektoral dalam pembentukan peraturan perundang-undangan lebih kuat disbanding pendekatan sistem;

4) Lemahnya koordinasi dalam proses pembentukan peraturan perundangundangan yang melibatkan berbagai instansi dan disiplin hukum;

5) Akses masyarakat untuk berpartisipasi dalam proses pembentukan peraturan perundangundangan masih terbatas;

6) Belum mantapnya cara dan metode yang pasti, baku dan standar yang mengikat semua lembaga yang berwenang membuat peraturan perundang-undangan. ${ }^{22}$

Disharmonisasi peraturan perundangundangan mengakibatkan: 1) Terjadinya perbedaan penafsiran dan pelaksanaanya; 2) Timbulnya ketidakpastian hukum; 3) Peraturan perundang-undangan tidak terlaksana secara efektif dan efisien; 4) Terjadinya disfusi hukum, artinya hukum tidak dapat berfungsi memberikan pedoman berperilaku kepada masyarakat, penyelesaian sengketa dan sebagai sarana perubahan social secara tertib dan teratur. ${ }^{23}$

Menurut penulis cara mengatasi disharmonisasi peraturan perundang-undangan ada 3 (tiga) cara, yaitu:

1) Mengubah atau mencabut pasal tertentu yang mengalami disharmonisasi atau seluruh pasal peraturan perundang-undangan yang bersangkutan, oleh lembaga atau instansi yang berwenang membentuknya;

2) Mengajukan permohonan uji materil kepada lembaga yudikatif, sebagai berikut: a) untuk pengujian undang-undang terhadap Undang-undang Dasar kepada Mahkamah Konstitusi; dan b) untuk pengujian peraturan perundang-undangan di bawah undangundang terhadap undang-undang kepada Mahkamah Agung;

3) Menerapkan asas hukum/doktrin hukum sebagai berikut: a) Lex superior derogate legi inferiori; b) Lex specialis derogate legi generalis; c) Lex posterior derogate legi priori. Menurut penulis diantara ketiga asas hukum tersebut, cara untuk mengatasi disharmonisasi antara undang-undang kekuasaan kehakiman dengan undangundang arbitrase adalah dapat menerapkan asas lex specialis derogate legi generali.

Pengertian Asas Lex specialis derogate legi generalisitu sendirimenurut Bagir Manan dalam bukunya yang berjudul "Hukum Positif Indonesia", asas ini mengandung makna, bahwa aturan hukum yang khusus akan mengesampingkan aturan hukum yang umum. 
Ada beberapa prinsip yang harus diperhatikan dalam asas lex specialis derogate legi generalis: Ketentuan-ketentuan yang didapati dalam aturan hukum umum tetap berlaku, kecuali yang diatur khusus dalam aturan hukum khusus tersebut, yaitu:

1) ketentuan-ketentuan lex specialis harus sederajat dengan ketentuan-ketentuan lex generalis (undang-undang dengan undangundang).

2) ketentuan-ketentuan lex specialis harus berada dalam lingkungan hukum yang sama dengan lex generalis.

Apabila ada benturan hukum antara 2 (dua) peraturan yang kedudukannya sama, maka aturan yang lebih khusus yang digunakan, aturan yang bersifat umum itu tidak lagi sebagai hukum ketika telah ada aturan yang bersifat khusus. Dengan kata lain, aturan yang khusus itulah sebagai hukum yang valid, dan mempunyai kekuatan mengikat untuk diterapkan terhadap peristiwa-peristiwa konkrit. Penerapan asas ini menyebabkan suatu aturan hukum termasuk ketika hal itu terdapat dalam ketentuan peraturan perundang-undangan, menjadi tidak mempunyai kekuatan mengikat. Jadi dapat disimpulkan pula bahwa undang-undang kekuasaan kehakiman yang bersifat umum tidak lagi sebagai hukum ketika telah ada aturan yang bersifat khusus yaitu undang-undang arbitrase.

\section{Kekuatan Eksekutorial Putusan Arbitrase}

Kasus yang cukup menyita perhatian adalah sengketa yang terjadi antara Hary Tanoe Soedibjo dengan Siti Ardianti Rukmana dalam perjanjian Investment Agreement PT. Cipta Televisi Pendidikan Indonesia (TPI). Kasus tersebut adalah contoh betapa putusan arbitrase masih tidak ditaati. Kasus bermula saat PT Berkah milik Hari Tanoe merestrukturisasi utang TPI pada 2002 dan dibuatlah dokumen perjanjian investasi. Tahun 2005, PT Berkah mengambil alih saham Siti Ardianti Rukmana dari 100 persen menjadi 25 persen dan 75 persen milik PT Berkah. Tidak terima kemudian Siti Ardianti Rukmana mengadakan Rapat Umum Pemegang Saham Luar Biasa (RUPS LB) dan membentuk susunan dewan direksi baru. Dua hari berikutnya, giliran PT Berkah membuat RUPS LB dan juga membentuk dewan direksi baru. Oleh Kemenkum HAM, dewan direksi yang diakui adalah versi PT Berkah.Merasa dirugikan kemudian Siti Ardianti Rukmana mengajukan gugatan lewat jalur perdata ke pengadilan untuk konflik sengketa investasi tersebut. Di tingkat kasasi, MA memutuskan bahwa saham Siti Ardianti Rukmana di TPI harus dipulihkan, artinya TPI kembali dimiliki oleh Siti Ardianti Rukmana. Namun ternyata perjanjian investasi tersebut memuat klalusula arbitrase, yang hampir bersamaan dengan gugatan perdata diproses. PT. Berkah melakukan gugatan melalui Badan Arbitrase Nasional Indonesia (BANI). Dalam perkara ini BANI mengeluarkan putusan dengan nomor 547/XI/ARBBANI/2013 yang memutuskan bahwa Hary Tanoe berhak atas 75\% saham di TPI dan menyatakan bahwa Siti Hardiyanti Rukmana telah melakukan cidera janji dan karenaya harus membayar kepada Hary Tanoe sebesar Rp 510.043.408.297,00 (lima ratus sepuluh miliar empat puluh tiga juta empat ratus delapan ribu dua ratus sembilan puluh tujuh rupiah). Berdasarkan Pasal 61 UU Arbitrase maka putusan tersebut harus dilaksanakan berdasarkan perintah dari ketua Pengadilan Negeri. Putusan arbitrase tersebut ditolak oleh kubu Siti Hardianti, bahkan ia melaporkan secara pidana. Beruntungnya Hari 
Tanoe menguasai secara fisik eksistensi TPI, sehingga meskipun putusan BANI tersebut tidak diakui oleh Siti Hardianti, Hari Tanoe tetap menguasai fisik TPI. Berbeda dengan kasus di atas, kasus PERURI melawanBARUTAMA, PT. Indonesia Power Unit Bisnis Pembangkitan Semarang melawan konsorsium (PT. Boma Bisma Indra Persero- PT. Indo Surya Persada), dan kasus-kasus yang lain membuktikan bahwa putusan arbitrase tidak ditaati oleh pihak yang kalah.

Ujung penyelesaian sengketa arbitrase adalah putusan arbitrase sebagai inti dari pemecahan masalah. Putusan ada yang dimenangkan dan ada yang dikalahkan, kewajiban pihakyang kalah adalah memenuhi suatu prestasi yang kemudian menjadi hak keperdataan bagi pihak yang menang. Ada beberapa literatur dan UU Arbitrase yang mengatakan bahwa pada putusan arbitrase pada suatu sengketa yang terjadi di dalam negeri harus di daftarkan ke Pengadilan Negeri, jadi putusan arbitrase yang telah dibacakan dan harus didaftarkan dan diserahkan kuasanya ke Pengadilan Negeri melalui Panitera Pengadilan Negeri selambat-lambatnya 30 hari setelah putusan arbitrase diucapkan.

Proses pendaftaran putusan arbitrase ke Pengadilan Negeri ada yang memperoleh penolakan eksekusi terhadap putusan arbitrase denganalasantidakmemenuhi syarat. Penolakan terhadap pendaftaran putusan arbitrase oleh Pengadilan Negeri membuka peluang bagi pihak yang tidak puas terhadap suatu putusan arbitrase untuk mengajukan permohonan pembatalan putusan arbitrase. Kenyataannya di Indonesia yang menjadi permasalahan adalah putusan arbitrase menjadi kurang dapat dieksekusi, padahal sebenarnya telah mengikat para pihak yang bersengketa. Banyak permasalahan arbitrase yang berawal hanya diselesaikan melalui arbitrase atau non litigasi berakhir di Pengadilan Negeri. Oleh sebab itu, penulis membuat beberapa hal yang menjadi alasan mengapa putusan arbitrase kurang dapat segera dieksekusi atau dilaksanakan, yaitu:

\section{a. Pihak yang kalah melakukan perlawanan}

Pihak yang kalah melakukan perlawanan pada putusan arbitrase, yaitu: pihak yang kalah tidak mau dieksekusi dengan mempertahankan objek sengketa, misalnya dengan organisasi sosial, antar warga negara, dan lain sebagainya. Kemudian pihak yang kalah melakukan gugatan ke Pengadilan Negeri yang mengacu pada Pasal 10 Undang Undang Kekuasaan Kehakiman. Hal ini yang menyebabkan putusan arbitrase menjadi kurang dapat dieksekusi, padahal putusan arbitrase yang telah diucapkan oleh arbiter telah mengikat kedua belah pihak yang bersengketa.

Terdapat banyak sekali permasalahan yang terjadi antara para pihak yang bersengketa yang mengambil jalur non litigasi atau yang biasa dikenal dengan arbitrase, berakhir pada ketidakpuasan terhadap putusan arbitrase. Hal ini sangat sering terjadi pada pihak yang kalah dalam putusan yang telah dibacakan, dimana seharusnya penyelesaian melalui arbitrase sudah selesai. Pihak yang kalah dalam sengketa mengajukan keberatan ke pengadilan negeri dengan mendaftarkan melalui kuasanya ke Pengadilan Negeri kepada Panitera Pengadilan Negeri. Padahal yang sebenarnya telah tercantum secara jelas dan nyata pada Pasal 11 ayat (1) UU Arbitrase. Bunyi dari Pasal11 ayat (1) UU Arbitrase yang menyatakan bahwa para pihak tidak dapat mengajukan penyelesaian sengketa atau beda pendapat yang termuat 
dalam perjanjian ke Pengadilan Negeri. Hal ini jelas menyimpang dari UU Arbitrase.

Salah satu pihak yang mendaftarkan putusan arbitrase ke Pengadilan Negeri dan menjadikan putusan arbitrase tersebut menjadi kurang dapat dieksekusi. Inilah yang menjadi alasan penulis untuk memasukkan pihak yang kalah dalam sengketa arbitrase menjadi salah satu penyebab putusan arbitrase menjadi kurang dapat dieksekusi.

\section{b. Hakim Pengadilan Negeri menerima gugatan arbitrase}

Hakim Pengadilan Negeri menerima gugatan arbitrase, hal itu merupakan salah satu alasan mengapa putusan arbitrase menjadi kurang dapat dieksekusi. Hal ini tampak pada salah satu pihak khususnya pihak yang kalah dalam sengketa seringkali mengajukan putusan arbitrase ke pengadilan negeri.

Pengajuan putusan arbitrase benar adanya dicantumkan dalam UU Arbitrase secara jelas tertulis, namun mengapa harus didaftarkan ke Pengadilan Negeri apabila putusan arbitrase tersebut telah mempunyai kekuatan hukum tetap dan mengikat para pihak seperti yang tercantum pada Pasal 60 UU Arbitrase. Pengajuan putusan arbitrase ke pengadilan negeri sering diterima oleh pihak pengadilan, baik pihak pengadilan negeri maupun hakim di pengadilan negeri.

Pengajuan putusan arbitrase ke pengadilan sering diterima oleh hakim di pengadilan negeri. Hakim pengadilan negeri menerima gugatan arbitrase yang dilakukan salah satu pihak yang kalah. Hal itu dapat terjadi dikarenakan ketidaktauan hakim dan kurangnya itikad baik dari hakim itu sendiri, seperti: adanya suap yang diberikan pihak yang ingin menang dalam putusan tersebut. Tidak ada itikad baik dari hakim di pengadilan negeri ini juga menyimpang dari UU Arbitrase khususnya pada Pasal 3 dan Pasal 11 dan akhirnya walaupun diajukan banding ke Mahkamah Agung maka pengadilan negeri dinyatakan bersalah karena telah mengadili. Dalam UU Arbitrase tercantum secara jelas bahwa Pengadilan Negeri tidak berwenang untuk mengadili sengketa para pihak yang telah terikat perjanjian arbitrase seperti yang tertera dalam Pasal 3 UU Arbitrase, tetapi pada kenyataannya pengadilan negeri tetap menerima permasalahan antara kedua belah pihak yang saling bersengketa.

Bahwa Pengadilan Negeri tidak berhak mengadili sengketa para pihak yang terdapat didalam perjanjian arbitrase yaitu tercantum dalam Pasal 11 UU Arbitrase. Di Indonesia khususnya di pengadilan negeri tetap menerima dan mengadili permasalahan antara para pihak yang di dalamnya terdapat perjanjian arbitrase dengan mengutamakan itikad baik pengadilan negeri dan hakim di pengadilan negeri. Itikad baik dari pengadilan negeri dan hakim di pengadilan negeri ini secara nyata dan jelas telah menyalahi UU Arbitrase. Pasal 11 UU Arbitrase yang menyatakan adanya perjanjian arbitrase tertulis meniadakan hak para pihak untuk mengajukan penyelesaian sengketa ke pengadilan negeri dan pengadilan negeri harus menolak dan tidak akan campur tangan pada penyelesaian sengketa yang telah ditetapkan melalui arbitrase, kecuali dalam hal-hal tertentu.

Eksistensi putusan arbitrase terhadap gugatan oleh salah satu pihak melalui pengadilan yaitu putusan arbitrase bersifat final and binding bagi para pihak yang bersengketa, dan tidak terbuka upaya hukum apapun. Putusan yang sudah mempunyai kekuatan hukum yang tetap (krachtvan gewijsde power in force) tidak dapat diganggu gugat, itu artinya sudah tertutup 
kesempatan menggunakan upaya hukum untuk melawan putusan tersebut.

Kewenangan lembaga arbitrase dalam menyelesaikan sengketa para pihak telah diatur dalam undang-undang arbitrase namun, masih ada celah hukum yang dapat digunakan para pihak yang bersengketa yang tidak puas dengan putusan arbitrase yang sudah bersifat mengikat para pihak, sehingga para pihak dapat mengajukan gugatan kembali dalam sengketa yang sama melalui pengadilan negeri. Setiap celah hukum pasti kan dimanfaatkan oleh pihak-pihak yang dikecewakan atau dikalahkan. Persoalan yang melekat pada eksitensi lembaga arbitrase adalah ketergantunganya pada pengadilan. Meskipun pada dasarnya dapat diselesaikan oleh itikad baik para pihak, namun ketiadaan itikad baik menjadikan lembaga arbitrase tidak dapat mengeksekusi putusan. Oleh karana itu UU Arbitrase masih membuka keterlibatan lembaga pengadilan dalam konteks ini. Ada keharusan untuk mendaftarkan putusan arbitrase di pengadilan negeri. Hal ini menunjukkan bahwa lembaga arbitrase tidak mempunyai upaya pemaksa terhadap para pihak untuk taat dan tidak sekedar mengharapkan itikad baik.

Pihak yang kalah menganggap pengadilan negeri tidak akan menolak gugatan yang akan dilakukan dengan melihat Pasal 10 UU Kekuasaan Kehakiman. Hal itu menyebabkan disharmonisasi antara undang-undang kekuasaan kehakiman dengan undangundang arbitrase. Menurut penulis cara untuk mengatasi disharmonisasi di antara undangundang kekuasaan kehakiman dengan undangundang arbitrase adalah dapat menerapkan asas lex specialis derogate legi generali. Maka, asas lex specialis derogate legi generali menjadi solusi dalam menyelesaikan disharmonisasi kedua undang-undang tersebut. kemudian kewenangan absolut arbitrase berdasarakan Pasal 3 dan Pasal 11 UU Arbitrase.

Pada dasarnya gugatan yang dilakukan oleh salah satu pihak tidak dapat membatalkan putusan arbitrase karena menurut kekuatan hukumnya putusan arbitrase sudah final dan mengikat bagi para pihak yang bersengketa dan tidak terbuka upaya hukum apapun. Putusan yang sudah mempunyai kekuatan hukum yang tetap (krachtvan gewijsde power in force) tidak dapat diganggu gugat, itu artinya sudah tertutup kesempatan menggunakan upaya hukum untuk melawan putusan itu. Sifat mengikat putusan bertujuan untuk menetapkan suatu hak atau suatu hubungan hukum antara pihak-pihak yang berperkara, karena putusan arbiter sudah mengesampingkan peradilan umum untuk seluruhnya dan putusan dapat digunakan sebagai alat bukti oleh pihak yang berperkara. Namun lagi-lagi model jalan keluar demikian masih mengandalkan itikad baik dari hakim atau aparat penegak hukum. Untuk itu perlu dilakukan sinkronisasi antara UU Arbitrase dan Kekuasaan kehakiman dengan memberi batasan lebih tegas mengenai keterlibatan pengadilan dalam perkara yang ada klausula arbitrasenya. Sinkronisasi tersebut tidak boleh hanya ada di UU Arbitrase seperti saat ini, namun juga pada UU Kekeuasaan Kehakiman.

\section{Penutup}

Berdasarkan uraian di atas dapat disimpulkan bahwa kewenangan absolut penyelesaian sengketa dengan klausula arbitrase berada di lembaga arbitrase. Hal tersebut didasarkan pada ketentuan berdasarkan Pasal 3 dan 11 UU Arbitrase Klausula arbitrae mengandung arti bahwa lembaga arbitrase memiliki kewenangan absolut dalam menyelesaikan 
sengketa tersebut. Para pihak yang telah terikat dengan perjanjian arbitrase tidak mempuyai hak untuk mengajukan penyelesaian sangketa di Pengadilan Negeri.

Bahwa terdapat disharmoni antara UU Arbitrase dan UU Kekuasaan Kehakiman. Berdasarkan Pasal 3 dan 11 UU Arbitrase Pengadilan Negeri tidak berwenang untuk mengadili sengketa para pihak yang telah terikat dengan perjanjian arbitrase. Namun berdasarkan Pasal 10 UU Kekuasaan Kehakiman menyatakan bahwa Pengadilan dilarang menolak untuk memeriksa, mengadili, dan memutus suatu perkara yang diajukan dengan dalih bahwa hukum tidak ada atau kurang jelas, melainkan wajib untuk memeriksa dan mengadilinya. Sementara itu terhadap putusan arbitrase penting memiliki kekuatan eksekutorial. Inti dari kekuatan eksekutorial adalah ketaatan para pihak terhadap putusan tersebut dengan itikad baik. Ketiadaan itikad baik tidak menghilangkan kekuataan eksekutorial putusan arbitrase, karena putusan tersebut dimintakan eksekusi dengan mendaftarkan putusan arbitrase tersebut ke Pengadilan Negeri.

Dari hasil penelitian yang ada maka direkomendasikan bagi para pihak yang bersengketa dan telah memilih arbitrase sebagai model resolusi sengketa harus memahami dan mengedepankan itikad baik bahwa arbitrase memiliki kewenangan absolut untuk menyelesaikan sengketa mereka, oleh sebab itu para pihak harus menaati putusan arbitrase yang bersifat final dan binding, sehingga tidak ada perlawanan terhadap putusan tersebut, dan Instrumen pengadilan hanya untuk mengawal eksekusi/pelaksanaan putusan arbitrase.

Kemudian terhadap Hakim seharusnya tidak hanya menggunakan rasio legal pada UU Kekuasaan Kehakiman, tetapi harus juga memperhatikan prinsip court limitation dalam menerima atau menolak sengketa yang memiliki klausul arbitrase. Selain itu hakimjuga harus menerapkan asas lex specialis derogate legi generali. Sehingga ketika ada disharmoni antara UU Arbitrase dan UU Kekuasaan Kehakiman, maka UU Arbitrase diprioritaskan. Selain itu kepada pembuat undan-undang, agar tidak menimbulkan multi penafsiran maka perlu dilakukan sinkronisasi antara UU Arbitrase dan UU Kekuasaan Kehakiman. Rasio Legal UU Arbitrase sudah benar, sehingga Pasal 10 UU Kekuasaan kehakiman perlu dilakukan penyesuaian dengan memberikan pengecualian pada perkara yang ada klausul arbitrasenya.

\section{Daftar Pustaka}

\section{Buku}

A Sony Keraf, Etika Bisnis: Tuntutan dan Relevansinya, Pustaka Filsafat (Yogyakarta:Kanisius, 1998)

Bachtiar Efendi, dkk, Surat Gugat dan Hukum Pembuktian dalam Perkara Perdata (Bandung: Citra Aditya Bakti, 1992)

Bambang Sutiyoso, Penyelesaian Sengketa Bisnis (Yogyakarta: Citra Media, 2006)

Erman Rajagukguk, Arbitrase Dalam Putusan Pengadilan(Jakarta: Chandra Pratama, 2000)

Frans Hendra Winarta, Hukum Penyelesaian Sangketa; Arbitrase Nasional Indonesia dan Internasional (Jakarta: Sinar Grafika, 2013)

Gatot Soemartono, Arbitrase dan Mediasi di Indonesia (Jakarta: PT Gramedia Pustaka Utama, 2006)

Joni Emirzon, Alternatif Penyelesaian Sengketa di Luar Pegadilan (Jakarta:PT Gramedia Pustaka Utama, 2001)

Nurnaningsih Amriani, Mediasi Alternatif Penyelesaian Sengketa Perdata di Pengadilan (Jakarta: PT. Raja Grafindo Persada, 2012)

Peter Mahmud Marzuki, Penelitian Hukum (Jakarta: Kencana, Cet. 7, 2011)

Priyatna Abdurrasyid, Arbitrase \& Alternatif Penyelesaian Sengketa (Jakarta: Fikahati Aneska, 2002) 
Pujiyono, Eksistensi Model Penyelesaian Sengketa antara Nasabah dan Bank Syariah di Indonesia (Solo: SmartMedia, 2012)

Retnowulan Sutantio dan Iskandar Oeripkartawinata, Hukum Acara Perdata dalam Teori dan Praktek,(Bandung:Alumni, 1988)

\section{Jurnal/Artikel IImiah}

Franck, S. D. The Legitimacy Crisis in Investment Treaty Arbitration: Privatizing Public International Law Through Inconsistent Decisions, 73(4), (2005)

Drahozar, C. R. Party Autonomy and Interim Measures In International Commercial Arbitration, 189 (2003)

lossa, E. Reputational Concerns in Arbitration: Decision Bias and Information Acquisition, (June) (2007)

Jean R. Sternlight. HeinOnline -- 74 Wash. U. L. Q. 637 1996. (1996)

M. Khoidin, Pelaksanaan Asas Peradilan Cepat, Artikel(Surabaya:Harian Surya, 1996)
Marwah M. Diah, Prinsip dan Bentuk-bentuk Alternatif Penyelesaian Sengketa di Luar Pengadilan. Jurnal Hukum dan Dinamika Masyarakat. Vol. 5 (2008)

Sewart, K. Online Arbitration Of Cross-border, Business To Consumer Disputes, 56 (2002)

\section{Internet}

Direktorat Jenderal Kementerian Hukum dan HAM, "Harmonisasi Peraturan Perundang-undangan", http://ditjenpp.kemenkumham.go.id/htn-danpuu/421-harmonisasi-peraturan-perundangundangan.html, Direktorat Jenderal Peraturan Perundang-Undangan, (diakses 15 April 2018).

\section{Peraturan}

Undang-Undang Nomor 30 Tahun 1999 tentang Arbitrase dan Alternatif penyelesaian Sengketa

Undang-Undang Nomor 48 Tahun 2009 tentang Kekuasaan Kehakiman 